\title{
Evaluasi Aktivitas Antioksidan dan Perubahan Metabolit Sekunder Mayor Temulawak (Curcuma xanthorriza) Pada Umur Rimpang Yang Berbeda
}

Penulis

Afiliasi
Edy Djauhari Purwakusumah ${ }^{1,2}$, Lusi Royani ${ }^{1}$, Mohamad Rafi ${ }^{2,3^{*}}$

${ }^{1}$ Departemen Biokimia, Institut Pertanian Bogor, Indonesia

${ }^{2}$ Pusat Studi Biofarmaka, LPPM Institut Pertanian Bogor, Indonesia

${ }^{3}$ Departemen Kimia, Institut Pertanian Bogor, Indonesia

\section{Kata Kunci \\ - Temulawak \\ O C. xanthorriza \\ O Aktivitas antioksidan \\ O Kurkuminoid \\ O Xanthorizol \\ $\rightarrow$ Spektrum IR}

Diterima 25 Juni 2015 Direvisi 18 Agustus 2015 Disetujui 22 Februari 2016

*Penulis korespondensi Mohamad Rafi

Pusat Studi Biofarmaka LPPM Institut Pertanian Bogor Jl. Taman Kencana No. 3 Bogor, Indonesia 16128 Tel. +62-251 8373561 mra@ipb.ac.id

\begin{abstract}
Abstrak
Penelitian ini dilakukan untuk mengevaluasi aktivitas antioksidan dan perubahan metabolit sekunder mayor temulawak (C. xanthorrhiza) pada umur rimpang yang berbeda. Aktivitas antioksidan ditentukan menggunakan tiga metode yaitu DPPH (1,1-difenil-1-pikrilhidrazil), FRAP (ferric reducing antioxidant power), dan CUPRAC (cupric ion reducing antioxidant capacity), sedangkan kadar kurkuminoid dan xantorizol ditentukan dengan metode KCKT. Hasil pengukuran aktivitas antioksidan, kadar kurkuminoid dan xantorizol menunjukkan semakin meningkat dengan bertambahnya umur rimpang temulawak. Analisis korelasi antara aktivitas antioksidan dan kadar kurkuminoid serta xantorizoldiperoleh bahwa kapasitas antioksidan yang diukur dengan metode DPPH dan FRAP mempunyai korelasi positif dengan nilai sebesar $0.757 \leq r \leq 0.996$ dan $0.522 \leq r \leq 0.976$ berturut-turut, sedangkan metode CUPRAC berkorelasi tinggi dengan jumlah rendemen ( $r=0.986)$. Analisis spektrum IR pada sampel rimpang temulawak memberikan profil yang identik dengan perbedaan hanya pada nilai absorbansnya. Rimpang temulawak dengan umur 9 bulan memiliki detail spektrum IR yang lebih jelas dan nilai absorbans yang lebih tinggi dibandingkan dengan umur rimpang 7 dan 8 bulan. Evaluasi yang dilakukan dapat memberikan informasi mengenai mutu rimpang temulawak berdasarkan masa tanamnya.
\end{abstract}

\section{Pendahuluan}

Temulawak (Curcuma xanthorrhiza Roxb) merupakan tanaman asli Indonesia yang mempunyai spektrum aktivitas biologis yang luas seperti antibakteri, antiinflamasi, antioksidan, antitumor, dan hepatoprotektif (Itokawa et al. 1985; Ozaki 1990; Masuda et al. 1992; Lin et al. 1996; Hwang et al. 2000). Metabolit sekunder mayor yang berperan dalam berbagai efek farmakologi yang ditimbulkan oleh temulawak yaitu kurkuminoid dan xantorizol (Itokawa et al. 2002). Kurkuminoid merupakan kelompok senyawa diarilheptanoid yang bertanggung jawab 
menimbulkan warna kuning hingga jingga pada rimpang temulawak (Rafi et al. 2011) sedangkan xantorizol termasuk ke dalam kelas senyawa seskuiterpenoid. Fitur komposisi senyawa dapat berbeda pada spesies yang sama bergantung pada umur tumbuhan, cara budidaya, kondisi lingkungan tempat tumbuh (asal geografis), waktu panen, dan proses pasca panen maupun penyimpanannya (Alaerts et al. 2010; Sahoo et al. 2010). Varisasi ini dapat menyebabkan inkonsistensi dalam hal keamanan, efikasi, dan stabilitas produk obat herbal.Hal ini dibuktikan oleh Adzkiya (2006) dan Nurcholis (2006) yang menyatakan bahwa umur tanaman berpengaruh secara signifikan terhadap kandungan kurkuminoid maupun xantorizol temulawak. Secara umum temulawak dipanen setelah mencapai umur $7-8$ bulan atau setelah daunnya menguning dan kering.

Untuk mengetahui perubahan komposisi senyawa maupun aktivitas biologis akibat umur tumbuhan yang berbeda memerlukan suatu evaluasi terhadap kadar senyawa metabolit sekunder mayor yang aktif dan aktivitas biologisnya. Pemrofilan komposisi senyawa metabolit sekunder dan korelasinya dengan suatu aktivitas biologis memungkinkan secara nyata penyediaan informasi fungsional dengan memberikan gambaran mengenai keadaan biokimia suatu tumbuhan sehingga dapat digunakan untuk pemantauan kualitas bahan baku obat herbal. Aktivitas yang akan dikorelasikan dengan kurkuminoid dan xantorizol temulawak yaitu antioksidan karena aktivitas biologis ini memiliki spektrum aktivitas yang luas karena umumnya penyakit bersumber pada radikal bebas yang terbentuk pada tubuh makhluk hidup. Pada penelitian ini, penulis telah melakukan evaluasi aktivitas antioksidan menggunakan metode DPPH, FRAP, dan CUPRAC, pengukuran kadar kurkuminoid dan xantorizol serta korelasi antara aktivitas antioksidan dengan kadar kurkuminoid dan xantorizol. Sebagai tambahan informasi, evaluasi juga dilakukan dengan pemrofilan keseluruhan senyawa yang dikandung oleh temulawak menggunakan spektrum inframerah (IR). Melalui hasil penelitian ini diharapkan menjadi inisiasi pengembangan metode standardisasi bahan baku obat menggunakan konsep menyeluruh yaitu mengevaluasi komposisi senyawa bioaktif dan aktivitas biologisnya.

\section{Metode Penelitian}

\section{Alat dan Bahan}

Peralatan yang digunakan untuk penelitian ini yaitu kromatografi cair kinerja tinggi LaChrom Elite dengan detektor UV-Vis L-2420 (Hitachi, Jepang), spektrofotometer UV-Vis U-2800 yang dilengkapi dengan kuvet kuarsa $10 \mathrm{~mm}$ dan dioperasikan dengan peranti lunak UV solution versi 2.0 (Hitachi, Jepang), spektrofotometer inframerah tertransformasi Fourier Tensor 37 dengan detektor triglisina sulfat terdeuterasi yang dikontrol dengan peranti lunak Opus versi 4.2 (Bruker, Jerman), dan evaporator putar R-114 (Buchi, Swiss).

Bahan yang digunakan adalah rimpang temulawak umur 7, 8 dan 9 bulan yang diperoleh dari Tembalang, Semarang, Jawa Tengah. Vucher spesimen didepositkan di Pusat Studi Biofarmaka LPPM IPB. Pelarut pengekstrak menggunakan etanol teknis sedangkan untuk fase gerak KCKT menggunakan pelarut dengan tingkat HPLC (Merck, Darmstadt, Jerman). Bahan lain yang digunakan yaitu etanol p.a, metanol p.a yang dibeli dari Merck (Darmstadt, Jerman), kupri klorida dua hidrat, neokuproin, ammonium asetat, feri klorida enam hidrat, 2,4,6-tripiridil-s-triazina (TPTZ), asam klorida, asam asetat, difenilpikrilhidrazina, troloks, asam asetat yang dibeli dari Sigma-Aldrich (Palo Alto, Amerika Serikat), senyawa standar kurkumin, demetoksi kurkumin, dan bisdemetoksi kurkumin diperoleh dari Chromadex (Santa Ana, Amerika Serikat) sedangkan untuk xantorizol didonasikan oleh Prof J.K. Hwang (Yonsei University, Korea Selatan).

\section{Preparasi dan ekstraksi sampel}

Rimpang temulawak segar dicuci bersih, kemudian diiris tipis dengan ketebalan $\pm 5 \mathrm{~mm}$. Setelah itu sampel dikeringkan dalam oven hingga kering dengan suhu oven yang digunakan sebesar 40 ${ }^{\circ} \mathrm{C}$. Setelah kering, sampel dibuat menjadi serbuk dengan ukuran 100 mesh. Ekstraksi sampel dilakukan menggunakan cara maserasi selama 24 jam dengan sesekali diaduk. Rasio perbandingan bobot sampel 
dan pelarut pengekstrak sebesar 1:10. Ekstrak dipekatkan dengan penguap vakum putar yang kemudian dikeringkan menggunakan pengering bekuan.

\section{Aktivitas antioksidan dengan metode DPPH}

Metode DPPH yang digunakan mengacu kepada Blois (1958) yang telah dimodifikasi oleh Aqil et al. (2006). Larutan DPPH disiapkan dalam metanol dengan konsentrasi $0.1 \mathrm{mM}$. Sebanyak $100 \mu \mathrm{L}$ larutan ekstrak dengan konsentrasi $100 \mu \mathrm{g} / \mathrm{mL}$ ditambahkan ke dalam $2 \mathrm{~mL}$ larutan DPPH $0.1 \mathrm{mM}$ dalam metanol.Semua larutan dihomogenkan dengan vortex yang kemudian didiamkan selama 30 menit pada suhu ruang yang terlindung dari cahaya. Selanjutnya absorbans larutan tersebut diukur pada panjang gelombang $517 \mathrm{~nm}$. Blangko yang digunakan adalah pereaksi tanpa penambahan ekstrak. Troloks dengan rentang nilai konsentrasi antara 20-400 $\mu \mathrm{M}$ digunakan dalam membuat kurva kalibrasi dalam menentukan kapasitas antioksidan yang dinyatakan dalam $\mu \mathrm{mol}$ ekuivalen troloks/g ekstrak. Pengukurannya dilakukan tiga kali ulangan.

\section{Aktivitas antioksidan dengan metode FRAP}

Metode FRAP yang digunakan mengacu kepada Benzie \& Strain (1996). Pereaksi FRAP dibuat dengan mencampurkan bufer asetat $300 \mathrm{mM}(\mathrm{pH}$ 3.6), TPTZ $10 \mathrm{mM}$ dalam $40 \mathrm{ml}$ dan $20 \mathrm{mM}$ feri klorida enam hidrat dengan rasio 10:1:1. Sebanyak $3 \mathrm{~mL}$ reagen FRAP disiapkan dalam tabung reaksi, kemudian ditambahkan $100 \mu \mathrm{L}$ sampel yang memiliki konsentrasi $250 \mu \mathrm{g} / \mathrm{mL}$ dan $300 \mu \mathrm{L}$ akuades. Selanjutnya campuran tersebut dihomogenkan dengan vorteks dan didiamkan selama 30 menit pada suhu $37{ }^{\circ} \mathrm{C}$ selama 30 menit.Setelah itu, semua larutan uji dibaca absorbansnya pada panjang gelombang $593 \mathrm{~nm}$. Blangko yang digunakan adalah pereaksi tanpa penambahan ekstrak. Troloks dengan rentang nilai konsentrasi antara 100-600 $\mu \mathrm{M}$ digunakan dalam membuat kurva kalibrasi dalam menentukan kapasitas antioksidan yang dinyatakan dalam $\mu \mathrm{mol}$ ekuivalen troloks/g ekstrak. Pengukurannya dilakukan tiga kali ulangan.

\section{Aktivitas antioksidan dengan metode CUPRAC}

Prosedur pengukuran aktivitas antioksidan dengan metode CUPRAC mengacu kepada Apak et al.
(2004). Sebanyak $1 \mathrm{~mL}$ larutan kupriklorida $0.001 \mathrm{M}$, $1 \mathrm{~mL}$ larutan neokuproin (dalam etanol) $0.0075 \mathrm{M}$, dan $1 \mathrm{~mL}$ larutan buffer ammonium asetat $\mathrm{pH} 7$ ditambahkan ke dalam $0.1 \mathrm{~mL}$ akuades dan $1 \mathrm{~mL}$ larutan ekstrak yang memiliki konsentrasi $100 \mu \mathrm{g} / \mathrm{mL}$. Campuran kemudian di homogenkan dengan vorteks dan di diamkan selama 1 jam tanpa terkena cahaya pada suhu kamar. Selanjutnya larutan diukur absorbansnya pada panjang gelombang $457 \mathrm{~nm}$. Blangko yang digunakan adalah pereaksi tanpa penambahan ekstrak. Troloks dengan rentang nilai konsentrasi antara 10-90 $\mu \mathrm{M}$ digunakan dalam membuat kurva kalibrasi dalam menentukan kapasitas antioksidan yang dinyatakan dalam $\mu \mathrm{mol}$ ekuivalen troloks/g ekstrak. Pengukurannya dilakukan tiga kali ulangan.

\section{Penentuan kadar kurkuminoid}

Metode penentuan kadar kurkuminoid yang digunakan mengacu kepada metode yang telah dijabarkan oleh Jayaprakasha et al. (2002) menggunakan KCKT. Sistem KCKT yang digunakan yaitu: Kolom C18 (300 x $4.6 \mathrm{~mm}$ id) sebagai fase diam dan campuran asetonitril, asam asetat $2 \%$ dan metanol dengan elusi gradien sebagai fase gerak. Laju alir fase gerak yang digunakan sebesar $1 \mathrm{~mL} / \mathrm{menit}$, volume injeksi sampel sebanyak $20 \mu \mathrm{L}$, dan deteksi menggunakan detektor UV-Vis pada panjang gelombang $425 \mathrm{~nm}$. Kurva kalibrasi untuk analisis kuantitatif kurkuminoid dibuat dengan kisaran konsentrasi sebesar $0.25-1.00 \mu \mathrm{g} / \mathrm{mL}$. Larutan ekstrak dan standar disaring menggunakan filter $0.2 \mu \mathrm{m}$ sebelum diinjeksikan ke dalam KCKT. Pengukuran kadar dilakukan tiga kali ulangan.

\section{Penentuan kadar xantorizol}

Metode penentuan kadar xantorizol yang digunakan mengacu kepada metode yang dikembangkan oleh LG Company menggunakan KCKT. Metode ini termasuk ke dalam paten yang dimiliki oleh LG Company sehingga tidak dapat dituliskan detailnya dalam tulisan ini. Sistem KCKT yang digunakan yaitu: Kolom C18 sebagai fase diam dan campuran larutan asam fosfat dan metanol dengan elusi gradien sebagai fase gerak. Laju alir fase gerak yang digunakan sebesar $1 \mathrm{~mL} /$ menit dan deteksi menggunakan detektor UV-Vis. Kurva kalibrasi untuk analisis kuantitatif xantorizol dibuat dengan kisaran 
konsentrasi sebesar $50-400 \mu \mathrm{g} / \mathrm{mL}$. Larutan ekstrak dan standar disaring menggunakan filter $0.2 \mu \mathrm{m}$ sebelum diinjeksikan ke dalam KCKT. Pengukuran kadar dilakukan tiga kali ulangan.

\section{Pembuatan spektrum IR}

Sebanyak $\pm 20 \mathrm{mg}$ ekstrak rimpang temulawak dicampurkan dengan $180 \mathrm{mg} \mathrm{KBr}$ untuk dijadikan pelet. Pelet dibuat dengan menggunakan hand press Shimadzu dengan tekanan $8 \mathrm{kN}$ selama 15 menit. Tablet sampel kemudian ditempatkan dalam kompartemen sample pada spektrofotometer FTIR. Spektrum IR dibuat pada daerah 4000-400 $\mathrm{cm}^{-1}$ dengan jumlah payar 32 menit dan resolusi $4 \mathrm{~cm}^{-1}$.

\section{Hasil dan Pembahasan}

\section{Rendemen, aktivitas antioksidan, kadar kurkuminoid, dan xantorizol}

Ektraksi metabolit sekunder dalam rimpang temulawak dalam penelitian ini menggunakan etanol sebagai pelarut dengan teknik maserasi.Rendemen ekstrak temulawak yang diperoleh berkisar antara 9.09-10.605\% (Tabel 1). Nilai rendemen ini menunjukkan banyaknya komponen yang terekstrak selama proses ekstraksi.

Rimpang yang berumur 8 bulan berdasarkan nilai rendemennya mengandung senyawa metabolit dengan jumlah lebih besar dibanding umur rimpang 7 dan 9 bulan. Tiga metode digunakan dalam pengukuran aktivitas antioksidan temulawak yang berbeda umur tanamnya yaitu DPPH, FRAP, dan CUPRAC. Ketiga metode ini mempunyai karakteristik masing-masing dan telah umum digunakan dalam pengukuran aktivitas antioksidan tumbuhan dengan mekanisme reaksi kimia yang mendasarinya yaitu melalui transfer elektron.Metode DPPH digunakan dalam penelitian ini karena merupakan metode yang paling banyak digunakan dalam mengukur aktivitas antioksidan secara in vitro pada tumbuhan obat (Zhou et al. 2004). Metode FRAP juga dipilih untuk digunakan karena uji ini dapat digunakan untuk kuantifikasi kapasitas antioksidan pada bermacam sistem biologis mulai dari ekstrak hingga senyawa murni (Katalinic et al. 2006). Metode CUPRAC dipilih untuk digunakan karena memiliki beberapa keuntungan seperti selektif, pereaksinya yang lebih stabil dibandingkan pereaksi kromogenik pada metode pengukuran aktivitas antioksidan lainnya serta dapat mengukur secara simultan antioksidan hidrofilik dan lipofilik (Apak et al. 2007). Pengukuran aktivitas antioksidan suatu sampel dengan metode yang berbeda mungkin akan memberikan hasil yang acak sehingga menjadi sulit untuk dibandingkan dan dapat pula menimbulkan ketidak cocokan. Oleh karena itu, kapasitas antioksidan ketiga metode yang digunakan dinyatakan sebagai ekivalen troloks dalam satuan milimolar troloks per gram ekstrak sampel. Troloks merupakan senyawa analog vitamin E yang larut dalam air. Kapasitas antioksidan yang dinyatakan dalam ekivalen troloks akan lebih bermakna dan terdeskripsikan dibanding yang dinyatakan dalam persen inhibisi. Nilai aktivitas antioksidan yang dinyatakan sebagai ekivalen troloks akan dibandingkan meskipun metode yang digunakan berbeda, sedangkan pada persen inhibisi aktivitas antioksidan hanya melihat persen hambatan minimum oleh senyawa antioksidan terhadap radikal atau logam radikal.

Aktivitas antioksidan dari temulawak dengan umur 7, 8, dan 9 bulan menggunakan tiga metode di atas menghasilkan nilai yang bervariasi (Tabel 1). Variasi nilai antioksidan ini disebabkan oleh berbedanya konsentrasi senyawa-senyawa metabolit

Tabel 1. Rerata nilai aktivitas antioksidan, kadar kurkuminoid dan xantorizol temulawak pada umur rimpang berbeda

\begin{tabular}{|c|c|c|c|c|c|c|c|}
\hline \multirow{2}{*}{ Umur rimpang (bulan) } & \multirow{2}{*}{ Rendemen (\%) } & \multicolumn{3}{|c|}{$\begin{array}{c}\text { Metode } \\
(\mu \mathrm{mol} \text { troloks/g ekstrak) }\end{array}$} & \multirow{2}{*}{$\begin{array}{l}\text { Kurkumin } \\
(\% \mathrm{~b} / \mathrm{b})^{*}\end{array}$} & \multirow{2}{*}{$\begin{array}{l}\text { Demetoksi } \\
\text { kurkumin } \\
(\% \mathrm{~b} / \mathrm{b})^{*}\end{array}$} & \multirow{2}{*}{$\begin{array}{c}\text { Xantorizol } \\
\text { (\%b/b)* }\end{array}$} \\
\hline & & DPPH & FRAP & CUPRAC & & & \\
\hline 7 & 9.12 & 11.143 & 5.660 & 42.794 & 11.711 & 7.613 & 8.232 \\
\hline 8 & 10.61 & 13.815 & 6.776 & 57.746 & 15.980 & 10.031 & 8.945 \\
\hline 9 & 9.09 & 14.105 & 6.521 & 45.225 & 18.103 & 10.025 & 10.990 \\
\hline
\end{tabular}

Keterangan: * berdasarkan bobot kering sampel 
Tabel 2. Hasil korelasi metabolit dengan aktivitas antioksidan ketiga metode

\begin{tabular}{|c|c|c|c|c|c|c|c|}
\hline \multirow{2}{*}{$\begin{array}{c}\text { Faktor } \\
\text { pengamatan }\end{array}$} & \multirow[b]{2}{*}{ Rendemen } & \multicolumn{3}{|c|}{ Metabolit } & \multicolumn{3}{|c|}{ Aktivitas Antioksidan } \\
\hline & & Kurkumin & $\begin{array}{l}\text { Demetoksi } \\
\text { kurkumin }\end{array}$ & Xantorizol & $\mathrm{DPPH}$ & FRAP & CUPRAC \\
\hline Rendemen & 1.000 & 0.177 & 0.489 & -0.287 & 0.409 & 0.665 & 0.986 \\
\hline Kurkumin & 0.177 & 1.000 & 0.945 & 0.892 & 0.971 & 0.852 & 0.337 \\
\hline $\begin{array}{l}\text { Demetoksi } \\
\text { kurkumin }\end{array}$ & 0.489 & 0.945 & 1.000 & 0.694 & 0.996 & 0.976 & 0.627 \\
\hline Xantorizol & -0.287 & 0.892 & 0.694 & 1.000 & 0.757 & 0.522 & 0.125 \\
\hline
\end{tabular}

sekunder yang ada dalam temulawak pada umur rimpang yang berbeda. Aktivitas antioksidan cenderung meningkat dengan bertambahnya umur temulawak kecuali saat menggunakan metode CUPRAC dimana sampel dengan umur 8 bulan memiliki aktivitas antioksidan tertinggi. senyawa bioaktif mayor yang terdapat dalam temulawak. Kurkuminoid suatu senyawa diaril heptanoid dan xantorizol suatu senyawa seskuiterpenoid merupakan senyawa kurkuminoid yang paling umum terkandung dalam temulawak dengan konsentrasi yang besar yaitu kurkumin dan demetoksi kurkumin sedangkan untuk bisdemetoksi kurkumin umumnya terdeteksi dalam jumlah yang kecil. Untuk sampel temulawak yang digunakan dalam penelitian ini, puncak bisdemetoksi kurkumin tidak terdeteksi sehingga kadar kurkuminoid yang dihitung hanya diwakili oleh kurkumin dan demetoksi kurkumin. Kadar kurkuminoid dan xantorizol tertinggi diperoleh dari sampel dengan umur rimpang 9 bulan. Kadar kurkuminoid dan xantorizol menunjukkan kenaikkan seiring dengan bertambahnya umur tanaman (Tabel 1). Perbedaan ini disebabkan oleh umur rimpang yang berbeda akan mempengaruhi kuantitas kurkuminoid dan xantorizol karena adanya pengaruh pada penerimaan unsur hara yang digunakan dalam proses biosintesis metabolit sekunder tersebut.

\section{Korelasi Antara Metabolit Terhadap Aktivitas Antioksidan}

Aktivitas antioksidan suatu sampel ditentukan oleh keberadaan senyawa oksidan di dalamnya.
Untuk melihatnya diperlukan suatu korelasi antara jumlah metabolit bioaktifnya dengan nilai aktivitas antioksidan yang dihasilkan. Korelasi antara kadar kurkuminoid dan xantorizol dengan metode DPPH memiliki hubungan korelasi yang tinggi yaitu berkisar antara $0.757 \leq r \leq 0.996$. Nilai ini menunjukkan hubungan yang kuat antara jumlah kurkuminoid dan xantorizol dengan aktivitas antioksidan sampel. Hal ini sesuai dengan yang telah diketahui secara luas bahwa kurkuminoid mempunyai aktivitas dalam menangkal suatu radikal akibat adanya gugus metoksi yang telah tersubstitusi oleh hidrogen pada strukturnya. Gugus inilah yang akan menyumbangkan atom hidrogen saat pengukuran aktivitas antioksidan menggunakan metode DPPH. Korelasi antara kadar kurkuminoid dan xantorizol dengan metode FRAP nilainya lebih rendah dibanding metode DPPH. Nilai korelasinyaberkisar antara $0.522 \leq r \leq 0.976$. Pada metode FRAP, oksidan kurkuminoid lebih mampu menangkal radikal dalam reaksi redoks dibandingkan xantorizol. Hal ini ditunjukkan dengan adanya perbedaan nilai korelasi antara keduanya. Kurkuminoid lebih berperan sebagai donor elektron dibandingkan xantorizol yang ditandai dengan nilai korelasi yang lebih besar dari 0.9. Nilai korelasi antara kadar kurkuminoid dengan aktivitas antioksidan hasil pengukuran dengan metode DPPH lebih besar dibandingkan pengukuran dengan metode FRAP. Hal ini disebabkan karena kurkuminoid lebih mampu menjerap radikal dibandingkan sebagai donor elektron sehingga nilai aktivitas antioksidan dengan metode DPPH lebih besar dibanding dengan metode 


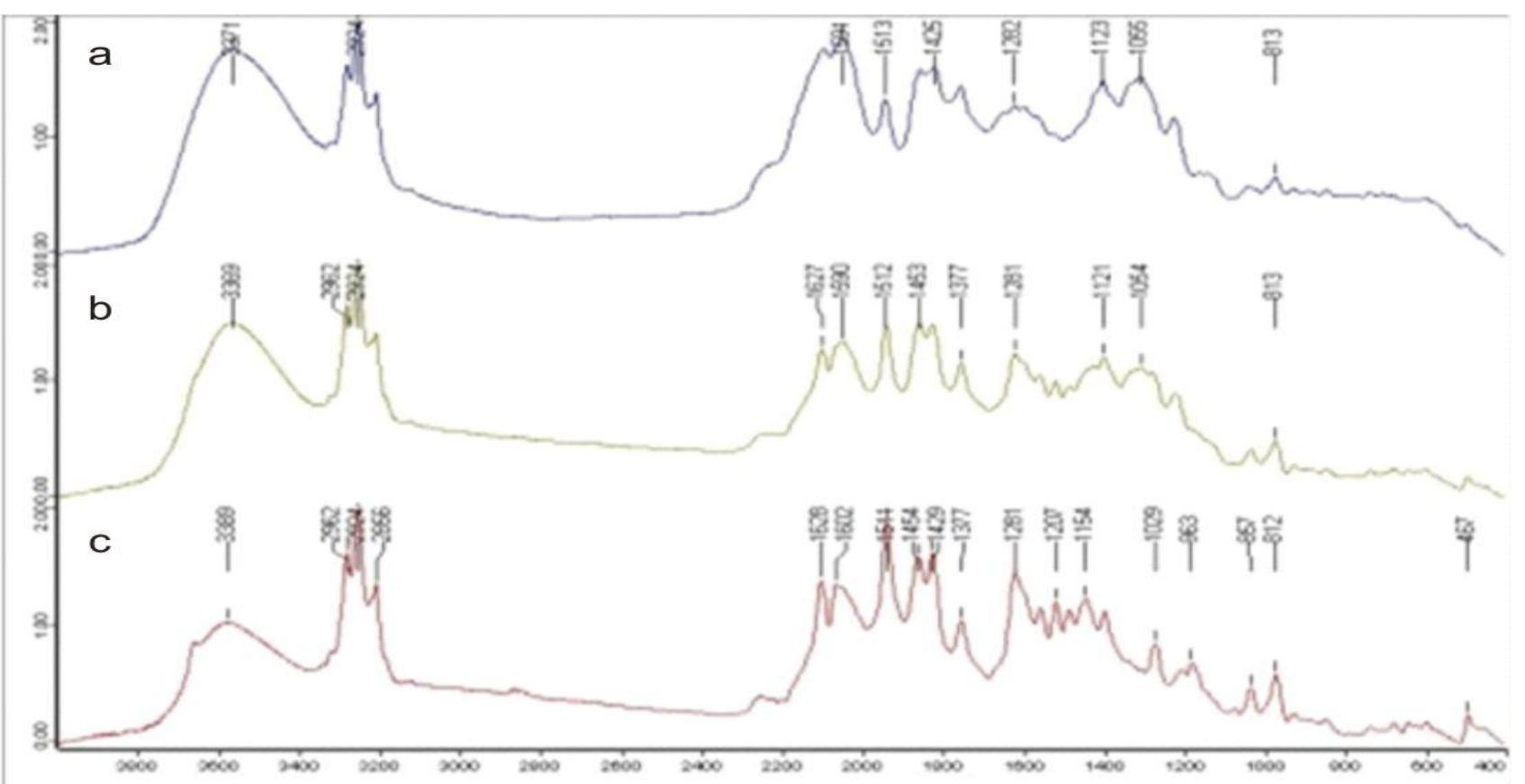

Gambar 1. Spektrum FTIR pada ekstrak rimpang temulawak umur 7 bulan (a), 8 bulan (b) dan 9 bulan (c).

FRAP. Korelasi antara kadar kurkuminoid dan xantorizol dengan aktivitas antioksidan yang diukur menggunakan metode CUPRAC menunjukkan hubungan korelasi yang lebih rendah dibanding dua metode sebelumnya yaitu sebesar $0.125 \leq r \leq 0.627$. Meskipun nilai korelasinya positif, nilai ini belum mampu menjelaskan hubungan antara mekanisme reaksi redoks pada metode CUPRAC dengan kurkuminoid maupun xantorizol. Metode CUPRAC menunjukkan hubungan yang sangat erat $(r=0.986)$ dengan jumlah rendemen pada taraf nyata $95 \%$ dengan kata lain semakin tinggi jumlah rendeman semakin tinggi pula aktivitas antioksidan pada metode CUPRAC. Hal ini sesuai dengan penelitian Apak (2004) yang mennyatakan bahwa metode CUPRAC mampu mengukur semua komponen antioksidan dalam matriks contoh.

\section{Analisis spektrum IR}

Spektrofotometri infra merah merupakan suatu teknik yang sering digunakan dalam identifikasi golongan senyawa kimia. akan memberikan banyak informasi yang berguna untuk menggambarkan ciri khas pada suatu sampel.Selain itu pula spektrum IR

Tabel 3. Dugaan gugus fungsi dan nilai absorbans dari spektrum ekstrak rimpang temulawak pada umur rimpang yang berbeda

\begin{tabular}{ccccc}
\hline \multirow{2}{*}{ Bilangan gelombang $\left(\mathrm{cm}^{-1}\right)$} & & \multicolumn{3}{c}{ Absorban } \\
\cline { 3 - 5 } & Dugaan gugus fungsi & 7 bulan & 8 bulan & 9 bulan \\
\hline $3389-3369(\mathrm{~s})$ & $\mathrm{OH}$ & 1.02 & 1.094 & 1.998 \\
$2962-2855(\mathrm{k})$ & $\mathrm{C}-\mathrm{H}\left(-\mathrm{CH}\right.$ dan $\left.-\mathrm{CH}_{3}\right)$ & 1.922 & 1.057 & 2.203 \\
$1628(\mathrm{k})$ & $\mathrm{C}=\mathrm{C}$ alkena & 1.391 & 1.231 & 1.425 \\
$1602(\mathrm{k})$ & $\mathrm{C}=\mathrm{C}$ (aromatik) & 1.454 & 1.274 & 1.423 \\
$1300-1000(\mathrm{k})$ & $\mathrm{C}-\mathrm{O}$ & 0.772 & 0.929 & 1.636 \\
$1513-1511(\mathrm{k}-\mathrm{s})$ & $\mathrm{N}-\mathrm{H}$ & 1.411 & 1.292 & 1.405 \\
\hline
\end{tabular}

Keterangan: $\mathrm{k}$ = kuat; $\mathrm{s}=$ sedang; $\mathrm{l}=$ lemah. 
dapat pula digunakan untuk melihat perubahan konsentrasi maupun profil metabolit dari suatu sampel tumbuhan. Spektrum IR rimpang temulawak dengan umur yang berbeda menunjukkan profil spektrum yang identik dengan perbedaan hanya terlihat pada nilai serapannya (Gambar 1). Interpretasi terhadap spektrum IR ekstrak rimpang temulawak menunjukkan adanya vibrasi dari beberapa gugus fungsi diantaranya $-\mathrm{OH},-\mathrm{CH}_{2}$ dan $\mathrm{CH}_{3}, \mathrm{C}=\mathrm{C}, \mathrm{C}-\mathrm{O}$, serta $\mathrm{N}-\mathrm{H}$ (Tabel 3). Hasil interpretasi dari semua spektrum memperlihatkan adanya perubahan metabolit dari ekstrak rimpang temulawak pada waktu tanam berbeda. Perbedaan terlihat jelas dari banyaknya puncak yang muncul dan ketajaman puncak dari setiap ekstrak yang menunjukkan gugus fungsi dari suatu senyawa metabolit. Puncak yang khas terlihat dari ekstrak rimpang umur 9 bulan.

\section{Kesimpulan}

Ekstrak rimpang temulawak dengan umur rimpang yang berbeda mempunyai aktivitas antioksidan yang relatif meningkat seiring umur rimpang yang bertambah kecuali saat diukur dengan menggunakan metode CUPRAC. Hal yang sama juga berlaku pada kadar kurkuminoid dan xantorizol yang kadarnya semakin meningkat dengan bertambahnya umur rimpang temulawak. Terdapat korelasi antara kadar kurkuminoid dan xantorizol dengan metode DPPH maupun FRAP, sedangkan untuk metode CUPRAC berkorelasi dengan rendemen. Analisis spektrum IR ekstrak rimpang temulawak memberikan profil yang identik hanya berbeda pada nilai absorbansnya. Rimpang temulawak dengan umur 9 bulan memiliki detail spektrum IR yang lebih jelas dan nilai absorbans yang lebih tinggi dibandingkan dengan umur rimpang 7 dan 8 bulan. Hasil ini dapat memberikan informasi mengenai kualitas bahan baku temulawak dengan umur rimpang yang berbeda terhadap aktivitas antioksidan maupun kadar metabolit mayor bioaktifnya.

\section{Daftar Pustaka}

Adzkiya MAZ. 2006. Pola akumulasi kurkuminoid rimpang temulawak (Curcuma xanthorriza Roxb) pada berbagai masa tanam dan perlakuan budidaya tanam [skripsi]. Bogor (ID) : Institut Pertanian Bogor.
Alaerts G, Dejaegher B, Smeyers-Verbeke J, Vander Heyden Y. 2010. Recent developments in chromatographic fingerprints from herbal products: set-up and data analysis. Comb Chemistry High Throughput Screening. 13: 900922.

Apak R, Kubilai GI, Zyrek M, Karademir SE. 2004. Novel total antioxidant capacity index for dietary poliphenols and vitamin $C$ ang $E$, using their cupric ion reducing in the presence neocuproine: cuprac method. Journal Agriculture Food Chemistry. 52:7970-7981.

Apak R, Guclu K, Demirata B, Ozyurek M, Celik SE, Bektasoglu B, Berker KI, Ozyurt D. 2007.Comparative evaluation of various total antioxidant capacity assays applied to phenolic compounds with the CUPRAC assay. Molecules. 12: 1496-1547.

Aqil F, Ahmad I, Mehmod Z. 2006. Antioxodant and free radical scavenging propreties of twelve traditionally used Indian medical plant. Turkey Journal Biology. 30: 177-183

Benzie IFF, Strain JJ. 1996. The ferric reducing ability of plasma (FRAP) as a measure of "Antioxidant Power": the FRAP assay. Analytical Biochemistry. 239: 70-76.

Hwang JK, Shim JS, Pyun YR. 2000. Antibacterial activity of xanthorrhizol from Curcuma xanthorrhiza against oral pathogens. Fitoterapia. 71: 321-323.

Itokawa $\mathrm{H}$, Shi Q, Akiyama T, Morris-Natschke SL, Lee KH. 2008. Recent advances in the investigations of curcuminoids. Chinese Medicine. 3: 11-23.

Jayaprakasha GK, Rao LMJ dan Sakarinah KK. 2002. Improved HPLC method for the determination of curcumin, demethoxy curcumin and bisdemethoxy curcumin. Journal Agriculture Food Chemistry. 50: 3668-3672

Katalinic V, Milos M, Kulisic T, Jukic M. 2006. Screening of 70 medicinal plants extracts for antioxidant capacity and total phenolics. Food Chemistry. 94: 550-557.

Lin SC, Lin YH, Supriyatna S. 1996.Protective and Therapeutic Effect of the Indonesian Medicinal Herb Curcuma xanthorrhiza on $\beta$-DGalactosamine induced Liver Damage. Phytotheraphy Research. 10: 131-135. 
Masuda T, Isobe J, Jitoe A, Nakatani M. 1992. Rafi M, Rohaeti E, Miftahudin A, Darusman LK. 2011. Antioxidative curcuminoids from rhizomes of Curcuma xanthorrhiza. Phytochemistry. 31: 3645-3647.

Nurcholis W. 2006. Kandungan xanthorrizol temulawak (Curcuma xanthorriza Roxb) pada berbagai cara budidaya dan masa tanam [skripsi]. Bogor (ID) : Institut Pertanian Bogor.

Ozaki Y. 1990. Anti-inflammatory effects of Curcuma xanthorrhiza Roxb, and its active principle. Chemical Pharmacy Bull, 38: 1045-1048. Differentiation of Curcuma Longa, Curcuma Xanthorrhiza and Zingiber Cassumunar by thin layer chromatography fingerprint analysis. Indonesia Journal Chemistry. 11: 71-74.

Sahoo N, Manchikanti P, Dey S. 2010. Herbal drugs: Standards and regulation. Fitoterapia. 81 : 462471.

Zhou K, Yu L. 2004. Effects of extraction solvent on the wheat bran antioxidant activity estimation. LWT-Food Science Technology. 37: 717-721. 